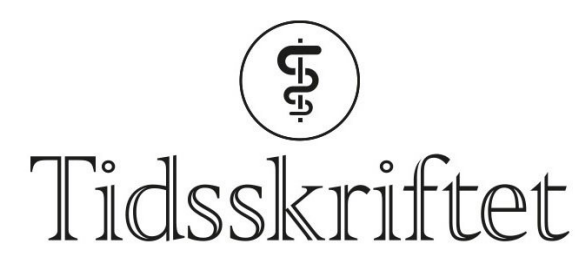

DEN NORSKE LEGEFORENING

\title{
Magneter i tarmen
}

MEDISINEN I BILDER

MAGNUS SCHISTAD

Avdeling for gastro- og barnekirurgi

Oslo universitetssykehus

Magnus Schistad er LIS1-lege.

Forfatteren har fylt ut ICMJE-skjemaet og oppgir ingen interessekonflikter.

\section{HANS SKARI}

Avdeling for gastro- og barnekirurgi

Oslo universitetssykehus

Hans Skari er ph.d., spesialist i generell kirurgi og i barnekirurgi og overlege.

Forfatteren har fylt ut ICMJE-skjemaet og oppgir ingen interessekonflikter.

\section{BEHZAD KHOSHNEWISZADEH}

Avdeling for radiologi og nukleærmedisin

Oslo universitetssykehus

Behzad Khoshnewiszadeh er spesialist i radiologi og overlege.

Forfatteren har fylt ut ICMJE-skjemaet og oppgir ingen interessekonflikter.

\section{OLE SCHISTAD}

Avdeling for gastro- og barnekirurgi

Oslo universitetssykehus

Ole Schistad er spesialist i generell kirurgi og i barnekirurgi og overlege.

Forfatteren har fylt ut ICMJE-skjemaet og oppgir ingen interessekonflikter.

\section{PÅL AKSEL N\&SS}

E-post: paanae@ous-hf.no Avdeling for traumatologi Oslo universitetssykehus

og

Institutt for klinisk medisin

Universitetet i Oslo

Pål Aksel Næss er spesialist i generell kirurgi og i barnekirurgi, overlege og professor.

Forfatteren har fylt ut ICMJE-skjemaet og oppgir ingen interessekonflikter. 

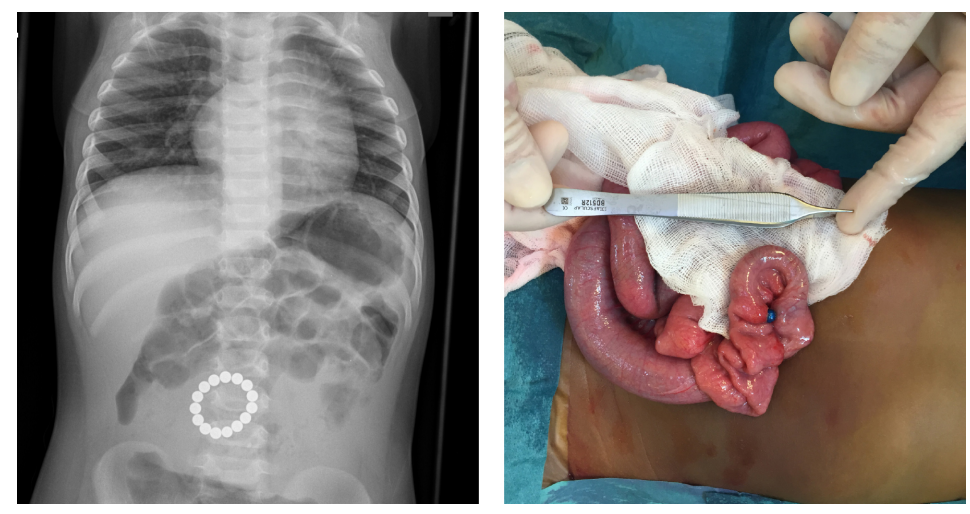

Røntgenbildet viser en krans av sirkulære fremmedlegemer intraabdominalt hos en ettåring. Pasienten ble innlagt med to dagers sykehistorie med oppkast.

Ved klinisk undersøkelse var barnet lett palpasjonsøm i buken, men ikke slippøm. Blodprøvesvar var upåfallende, med unntak av lett hypokloremisk alkalose og CRP på $25 \mathrm{mg} / \mathrm{L}$ (referanseområde o-4 mg/L). Pasientens mor ble vist røntgenbildet og mente det dreide seg om magnetiske kuler som tilhørte et søsken.

Pasienten ble laparotomert. Man påviste en ring med magnetkuler i tynntarmen om lag $70 \mathrm{~cm}$ fra det treitzke ligament. En av kulene hadde erodert gjennom tarmveggen, som vist på bildet tatt peroperativt. Magnetkulene ble fjernet, og det var nødvendig med tarmreseksjon med primær anastomose. Pasienten ble utskrevet i god allmenntilstand femte postoperative dag, men ble innlagt på nytt to dager senere med sårruptur. Denne ble operativt korrigert, og barnet kunne utskrives tredje dag etter inngrepet.

Det er ikke uvanlig at små barn svelger fremmedlegemer. I mange tilfeller skjer dette uten at foresatte er klar over hendelsen, og storparten passerer komplikasjonsfritt gjennom gastrointestinalkanalen (1). Svelgede magneter kan forårsake livstruende skader med obstruksjon og perforasjon om tarmveggen kommer i klem mellom magnetene, som i denne og en tidligere omtalt kasuistikk i Tidsskriftet (2). Mistanke om at et barn har svelget magneter er indikasjon for videre utredning med røntgen oversikt abdomen som første tiltak (3). Dersom fremmedlegemet kan være lokalisert i spiserøret, vil røntgen thorax også være indisert.

\section{LITTERATUR:}

1. Wright CC, Closson FT. Updates in pediatric gastrointestinal foreign bodies. Pediatr Clin North Am 2013; 6o: 1221-39. [PubMed][CrossRef]

2. Fjeldsbø WM, Aukland SM, Tjora E. Farlig tiltrekning. Tidsskr Nor Legeforen 2014; 134: 1244 . [PubMed][CrossRef]

3. Hussain SZ, Bousvaros A, Gilger M et al. Management of ingested magnets in children. J Pediatr Gastroenterol Nutr 2012; 55: 239-42. [PubMed][CrossRef]

Publisert: 11. desember 2020. Tidsskr Nor Legeforen. DOI: 10.4045/tidsskr.20.046o

Mottatt 19.5.2020, første revisjon innsendt 17.10.2020, godkjent 26.10.2020.

(C) Tidsskrift for Den norske legeforening 2020. Lastet ned fra tidsskriftet.no 